\title{
Dynamic formation of extreme ozone minimum events over the Tibetan Plateau during northern winters 1987-2001
}

\author{
Chuanxi Liu, ${ }^{1,2}$ Yi Liu, ${ }^{1}$ Zhaonan Cai, ${ }^{1,2}$ Shouting Gao, ${ }^{3}$ Jianchun Bian, ${ }^{1}$ Xiong Liu, ${ }^{4,5}$ \\ and Kelly Chance ${ }^{6}$ \\ Received 1 September 2009; revised 20 April 2010; accepted 21 April 2010; published 24 September 2010.
}

[1] Wintertime extreme ozone minima in the total column ozone over the Tibetan Plateau (TP) between 1978 and 2001 are analyzed using observations from the Total Ozone Mapping Spectrometer (TOMS), Global Ozone Monitoring Experiment (GOME), and reanalysis data from both National Centers for Environmental Prediction and European Centre for Medium-Range Weather Forecasts. Results show that total column ozone reduction in nine persistent (lasting for at least 2 days) and four transient events can be substantially attributed to ozone reduction in the upper troposphere and lower stratosphere region (below $25 \mathrm{~km}$ ). This reduction is generally caused by uplift of the local tropopause and northward transport of tropical ozone-poor air associated with an anomalous anticyclone in the upper troposphere. These anticyclonic anomalies are closely related to anomalous tropical deep convective heating, which is, however, not necessarily phase locked with the tropical Madden-Julian Oscillation as in our earlier case study. Considering stratospheric processes, the selected 13 events can be combined into nine independent events. Moreover, five of the nine independent events, especially the persistent events, are coupled with contributions from stratospheric dynamics between 25 and $40 \mathrm{~km}$, i.e., $15 \%-40 \%$ derived from GOME observations for events in November 1998, February 1999, and December 2001. On the basis of these events, stratospheric column ozone reduction over the TP region can be attributed to the dynamics (development and/or displacement) of the two main stratospheric systems, namely, the polar vortex and the Aleutian High. The effect of a "lowozone pocket" inside the Aleutian High on the total column ozone in East Asia requires further study.

Citation: Liu, C., Y. Liu, Z. Cai, S. Gao, J. Bian, X. Liu, and K. Chance (2010), Dynamic formation of extreme ozone minimum events over the Tibetan Plateau during northern winters 1987-2001, J. Geophys. Res., 115, D18311, doi:10.1029/2009JD013130.

\section{Introduction}

[2] The Tibetan Plateau (TP), located in the latitude band $27.5^{\circ}-37.5^{\circ} \mathrm{N}$ with an average elevation of over $4000 \mathrm{~m}$ above sea level, is the highest plateau in the world, often titled the "third pole" [e.g., Qiu, 2008]. This vast, elevated plateau

\footnotetext{
${ }^{1}$ Key Laboratory of Middle Atmosphere and Global Environment Observation, Institute of Atmospheric Physics, Chinese Academy of Sciences, Beijing, China.

${ }^{2}$ Also at Graduate University of Chinese Academy of Sciences, Beijing, China.

${ }^{3}$ LACS, Institute of Atmospheric Physics, Chinese Academy of Sciences, Beijing, China.

${ }^{4}$ Goddard Earth Sciences and Technology Center, University of Maryland, Baltimore, Maryland, USA.

${ }^{5}$ Also at Harvard-Smithsonian Center for Astrophysics, Cambridge, Massachusetts, USA.

${ }^{6}$ Harvard-Smithsonian Center for Astrophysics, Cambridge, Massachusetts, USA.

Copyright 2010 by the American Geophysical Union. 0148-0227/10/2009JD013130
}

and its dynamic and thermal effects play important roles in both regional and global general circulation and weather systems [Yeh and Gao, 1979]. After the discovery of wintertime and springtime ozone depletion in the Antarctic [Farman et al., 1985] and Arctic [e.g., Manney et al., 1994], much recent attention has been paid to the variation of total column ozone (TCO) over the "third pole" [e.g., Zhou et al., 1995; Zou, 1996]. Because of the shallow vertical depth of the atmospheric column, the TCO over the TP is much lower than over other locations of the same latitudes. In summer, the Asian summer monsoon anticyclone in the upper troposphere (also called the South Asia High) is a crucial component of the monsoon system. Meanwhile, variations in the local tropopause height and isentropic surfaces associated with enhanced convection contribute to the formation of the summertime minimum in TCO [Zou, 1996]. The deep convection and isolation effects related to the summer monsoon anticyclone can also strongly influence the behavior of regional constituents in the upper troposphere and lower stratosphere (UTLS) region [Randel and Park, 2006]. 
Recently, Liu et al. [2009b] observed a middle tropospheric ozone minimum over Tibet in June. This minimum is closely related to the poleward transport of ozone-poor equatorial air during monsoon outbursts. In addition, the seasonal cycle of the TP column ozone shows a wintertime minimum in its deviation from the zonal-mean amount [Zou, 1996]. That is why there are few ozone minimum events observed during the winter.

[3] However, Bian et al. [2006] reported an unusual wintertime ozone minimum over the TP in December 2003 based on an analysis of the Total Ozone Mapping Spectrometer (TOMS) observations. The area with the TCO lower than 220 DU was over $2,500,000 \mathrm{~km}^{2}$, and the minimum value was only 190 DU. Such rapid and localized reduction and recovery of TCO is called an "ozone minihole" $(\mathrm{OMH})$ event [Newman et al., 1988]. These events have frequently been observed throughout the midlatitudes of both hemispheres and show a geographic dependence, with greater frequency over the North Atlantic-European sector [James, 1998a; 1998b]. Dynamic processes contributing to OMHs in high latitudes of Europe have been well documented as the meridional transport of subtropical ozone-poor air near the tropopause level and the divergence of ozone-rich air out of the air column in the lower stratosphere [Koch et al., 2005; Keil et al., 2007]. Some extreme OMHs in Europe are also related to the equatorward displacement of the stratospheric polar vortex [Salby and Callaghan, 1993; James et al., 2000]. A general formation mechanism has already been conceptualized as the vertical dipole structure of potential vorticity (PV) anomalies [Koch et al., 2005]. This vertical dipole structure is generally caused by meridional transport of ozone-poor air at different levels, i.e., northward transport from lower latitudes in the lower stratosphere (negative PV anomalies) and southward transport from higher latitudes in the middle stratosphere (MS; positive PV anomalies). Recently, Antón et al. [2007] reported pronounced increases (43\% and $75 \%$ compared to January 2003 and 2005) in UV radiation measurements during an extreme $\mathrm{OMH}$ event over Spain in January 2004. However, fewer studies [e.g., Han et al., 2005; Bian et al., 2006] have been devoted to OMHs over the East Asia/western Pacific sector.

[4] Bian [2009] summarized the climatology of the $\mathrm{OMH}$ events over the TP. He attributed the formation of these lowozone events, including the case in December 2003, to dynamic processes in the UTLS region, i.e., the northward shift of the subtropical westerly jet in the upper troposphere and the resulting uplift of the local tropopause. However, the dynamic mechanism responsible for the UTLS processes remains unexplained. Previous studies noted the relationship between tropical convective heating and extratropical circulation anomalies [e.g., Rui and Wang, 1990; Hendon and Salby, 1994; Kiladis et al., 2001]. Recent studies also note a complex relationship between tropical ozone [Ziemke and Chandra, 2003; Tian et al., 2007] and the Madden-Julian Oscillation (MJO) [Madden and Julian, 1971, 1994]. On the basis of these results, C. Liu et al. [2009] revealed the dynamic relation between the UTLS anticyclonic circulation anomaly during the December $2003 \mathrm{OMH}$ event and the tropical convective heating associated with the MJO.

[5] On the other hand, Han et al. [2005] noted the association of the midstratospheric Aleutian High with the winter- time ozone minimum over the subtropical northwestern Pacific. The Aleutian High is a prominent planetary-scale feature in the MS during the northern winter [Harvey and Hitchman, 1996], which is closely associated with the vigorous poleward transport of tropical air masses [Harvey et al., 1999]. Prominent low-ozone centers, named "low-ozone pockets" (LOPs), are often observed inside the Aleutian High and can be explained by the dynamic isolation of air masses at high latitudes (with high solar zenith angles) over time periods that are long enough for local photochemical equilibrium to be approached [Manney et al., 1995; Morris et al., 1998]. Recent satellite observations further revealed that wintertime LOPs exist in the stratospheric anticyclones in both hemispheres [Harvey et al., 2004] and usually contribute as much as $\sim 10 \%$ of local TCO reduction [Harvey et al., 2008]. More recently, using Michelson Interferometer for Passive Atmospheric Sounding (MIPAS) and Global Ozone Monitoring by Occultation of Stars (GOMOS) ozone observations, C. Liu et al. [2009] reported that the displacement of Aleutian LOPs during the 2003-2004 stratospheric sudden warming (SSW) event prominently contributed $(\sim 29 \%-46 \%)$ to the record ozone minimum over the TP in December 2003. This is the first study to quantify stratospheric influence on the wintertime TCO over the TP region.

[6] During the 2003 event, the record ozone minimum over the TP mentioned by Bian et al. [2006] results from independent dynamic processes in the MS and UTLS regions. In the UTLS region, contributing factors are a lofting of the tropopause associated with deep convection as well as horizontal advection of tropical ozone-poor air to higher latitudes. The important mechanism in the MS region is the displacement of LOPs over the TP [C. Liu et al., 2009]. However, whether these dynamic mechanisms can be applied to other wintertime ozone minimum events over the TP and whether stratospheric dynamics can contribute to other ozone minimum events are still unknown. In this study, we test previous mechanisms for all the extreme ozone minimum events during the boreal winters of 1987-2001 [Bian, 2009] and provide a general conclusion about dynamic processes contributing to ozone minima over the TP region.

[7] This paper is organized in the following way: Section 2 introduces the data (reanalysis data and satellite observations) and the selection method of the ozone minimum events. Selected events and the vertical ozone profiles from satellite observations are presented in section 3. Section 4 analyzes dynamic processes in both UTLS and MS regions contributing to the ozone minimum events. Considering stratospheric processes, the 13 selected ozone minima are further combined into nine independent events. The main result is summarized and discussed in section 5 .

\section{Data and Method}

\subsection{Reanalysis Data}

[8] To analyze dynamics in the UTLS region, we use daily outgoing longwave radiation (OLR) and horizontal wind anomalies, based on the 1979-2008 climatology from the National Centers for Environmental Prediction-National Center for Atmospheric Research (NCEP-NCAR) reanalysis data [Kalnay et al., 1996]. Geopotential height and horizontal winds from the ERA-40 data [Uppala et al., 2005] are used to 
Table 1. Characteristics of Extreme Ozone Minima Over the Tibetan Plateau During 1978-2001 Winters, After a Previous Study ${ }^{\mathrm{a}}$

\begin{tabular}{|c|c|c|c|c|c|}
\hline No. & Duration (days) & Area $\left(10^{4} \mathrm{~km}^{2}\right)$ & Minimum (DU) & Latitude, Longitude (deg) & Type \\
\hline 1 & 29 Nov-1 Dec 1987 (3) & 133 & 205 & $32^{\circ} \mathrm{N}, 89^{\circ} \mathrm{E}$ & $\mathrm{P}$ \\
\hline 2 & 5-8 Dec 1987 (4) & 105 & 210 & $29^{\circ} \mathrm{N}, 91^{\circ} \mathrm{E}$ & $\mathrm{P}$ \\
\hline 3 & 9-12 Dec 1987 (4) & 189 & 194 & $34^{\circ} \mathrm{N}, 86^{\circ} \mathrm{E}$ & $\mathrm{P}$ \\
\hline 4 & 21-23 Dec 1987 (3) & 80 & 210 & $30^{\circ} \mathrm{N}, 85^{\circ} \mathrm{E}$ & $\mathrm{P}$ \\
\hline 5 & 2 Jan 1993 (1) & 47 & 212 & $32^{\circ} \mathrm{N}, 87^{\circ} \mathrm{E}$ & $\mathrm{T}$ \\
\hline 6 & 8-10 Feb 1993 (3) & 65 & 205 & $35^{\circ} \mathrm{N}, 77^{\circ} \mathrm{E}$ & $\mathrm{P}$ \\
\hline 7 & 17 Dec 1996 (1) & 41 & 205 & $29^{\circ} \mathrm{N}, 93^{\circ} \mathrm{E}$ & $\mathrm{T}$ \\
\hline 8 & 16 Nov 1998 (1) & 47 & 206 & $28^{\circ} \mathrm{N}, 91^{\circ} \mathrm{E}$ & $\mathrm{T}$ \\
\hline 9 & 19-23 Nov 1998 (5) & 97 & 204 & $28^{\circ} \mathrm{N}, 99^{\circ} \mathrm{E}$ & $\mathrm{P}$ \\
\hline 10 & 23-25 Jan 1999 (3) & 105 & 205 & $28^{\circ} \mathrm{E}, 90^{\circ} \mathrm{E}$ & $\mathrm{P}$ \\
\hline 11 & 19-20 Feb 1999 (2) & 77 & 207 & $33^{\circ} \mathrm{N}, 95^{\circ} \mathrm{E}$ & $\mathrm{P}$ \\
\hline 12 & 30 Oct 2000 & 63 & 208 & $35^{\circ} \mathrm{N}, 79^{\circ} \mathrm{E}$ & $\mathrm{T}$ \\
\hline 13 & $18-20$ Dec 2001 & 45 & 200 & $30^{\circ} \mathrm{N}, 84^{\circ} \mathrm{E}$ & $\mathrm{P}$ \\
\hline
\end{tabular}

${ }^{a}$ The 13 extreme events fall into two categories according to their durations: $\mathrm{P}$ indicates persistent events lasting for at least 2 days, while $\mathrm{T}$ indicates transient events only appearing for a single day. Data are from Bian [2009].

analyze the stratospheric dynamics (above the $50 \mathrm{hPa}$ pressure surface) contributing to the wintertime ozone minimum events over the TP region. The PV field from ERA-40 data is used to analyze the variations of the dynamical tropopause (section 4.1 and Figure 4) and the polar vortex (section 4.2 and Figures 5-10). As suggested by Hoerling et al. [1991], the tropopause analysis is based on the $3.5 \mathrm{PV}$ unit (PVU) isoline. As in our previous study [Y. Liu et al., 2009a], the polar vortex is represented by the modified PV contour (35 PVU). The definition of the modified PV (referenced to the $475 \mathrm{~K}$ potential temperature level) is provided by Lait [1994].

\subsection{TOMS and Global Ozone Monitoring Experiment (GOME) Observations}

[9] TCO level 3 products from the TOMS on board Nimbus-7 spacecraft (from November 1979 through March 1993) and from the Earth Probe TOMS (from August 1996 through December 2001) are used to determine the locations and magnitudes of all TCO minimum events during the 19872001 boreal winters. The TCO observations have global coverage except for the polar night region, with a horizontal resolution $1^{\circ} \times 1.25^{\circ}$ (latitude $\times$ longitude). They are available from National Aeronautics and Space Administration Goddard Space Flight Center. This data set has been used to study ozone minimum events in both hemispheres [e.g., James, 1998a, 1998b].

[10] The GOME was launched in 1995 on board the European Space Agency (ESA) Remote Sensing-2 (ERS-2) satellite. It measures backscattered radiance spectra from the Earth's atmosphere and surface over the wavelength range $240-790 \mathrm{~nm}$, with moderate spectral resolution of $0.2-0.4 \mathrm{~nm}$ and high signal-to-noise ratios. GOME provides vertical ozone distribution in both stratosphere and troposphere [Chance et al., 1997]. Ozone profiles are retrieved at 24 approximately $2.5 \mathrm{~km}$ layers from surface to $60 \mathrm{~km}$. Typical ground pixel size is $960 \times 80 \mathrm{~km}^{2}$. The vertical resolution is $8-15 \mathrm{~km}$ in the troposphere and $7-10 \mathrm{~km}$ in the stratosphere. In this study, GOME ozone profiles were retrieved by Liu et al. [2005] and have been compared with a number of satellite and ozonesonde observations [Liu et al., 2005, 2006]. Mean biases are generally within $15 \%-20 \%$ (the standard deviations of the differences in tropospheric ozone column between GOME and ozonesonde observations). Recently, GOME ozone profiles have also been validated with ob- servations at two Chinese ozonesonde stations (Lhasa and Xining) near the TP region and show consistency with the ozonesonde data; that is, the mean bias is within $10 \%$ between 16-32 km [Cai et al., 2009; Y. Liu et al., 2009b]. In section 3.1, the GOME ozone profiles and TCO from TOMS observations are compared to quantify contributions from MS dynamics during the ozone minimum events after 1995 (November 1998, January 1999, February 1999, and December 2001 events). In section 4.2, 10 day average ozone distribution in the stratosphere is constructed using GOME ozone profiles within East Asia.

\subsection{Event Selection}

[11] To study the extreme wintertime $\mathrm{OMH}$ events before 2002, we examined the daily TCO observations within the TP region $\left(25^{\circ}-40^{\circ} \mathrm{N}, 75^{\circ}-105^{\circ} \mathrm{E}\right)$ from the Nimbus-7 TOMS and the Earth Probe TOMS. First, we calculated the geographic area enclosed by each of the TCO isolines. Second, we selected the minimum TCO isoline whose area is larger than $400,000 \mathrm{~km}^{2}$ and defined its value as the daily minimum TCO. Finally, we computed the mean ( 250 DU) and standard deviation ( $\sim 15$ DU) of the wintertime (November, December, January, and February) daily minimum TCO between 1979 and 2001. To analyze the dynamic mechanisms contributing to extreme ozone minimum events, we use 220 DU (two standard deviations below the mean) as the threshold value in our event selection. Bian [2009] used the same threshold value and obtained 13 extreme $\mathrm{OMH}$ events during northern winters 1987-2001. In this study, we divide the 13 events into two categories, according to their duration (see Table 1). As a result, nine events fall into the persistent type (lasting for at least 2 days), while the other four events fall into the transient type (lasting for only a single day). In the following context (sections 3 and 4.1), only persistent events are used to show the mechanism responsible for ozone decrease in the UTLS region. However, this mechanism also applies to the transient events, where the dynamical anomalies are of smaller amplitude (not shown). As will be shown in section 4.2, the four persistent events in November and December 1987 are closely related with one another in terms of stratospheric dynamics and can be regarded as one single event (the November-December 1987 event). Therefore, only 2 days during the November-December 1987 event are compared with other events in section 4.1. Similarly, the two 
a) 29Nov-1Dec 1987

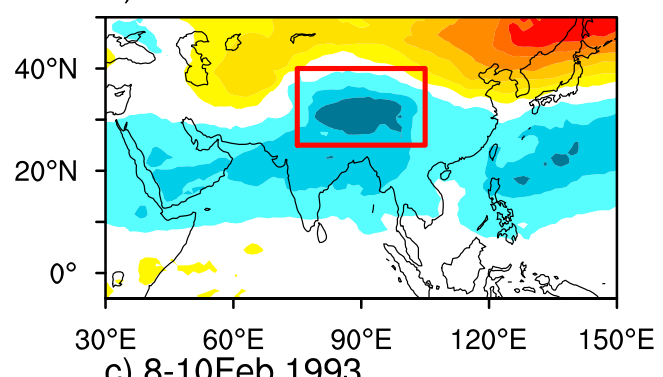

c) 8-10Feb 1993

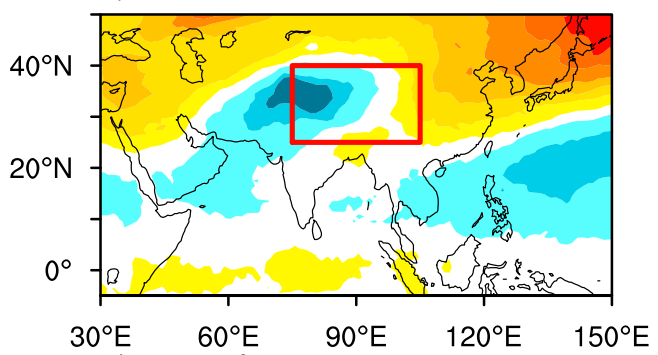

e) 23-25Jan 1999

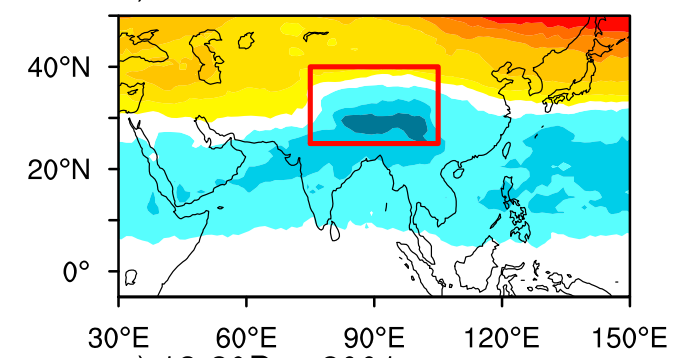

g) $18-20 \mathrm{Dec} 2001$

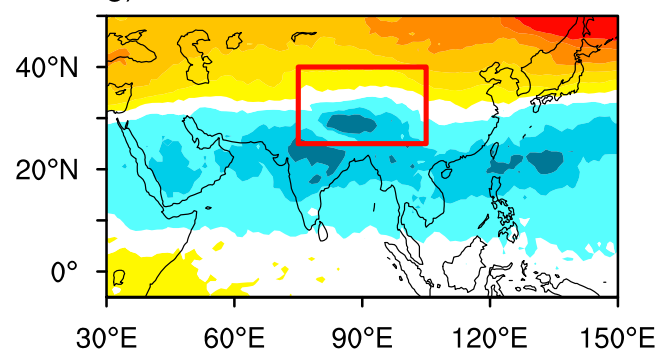

b) 9-12Dec 1987
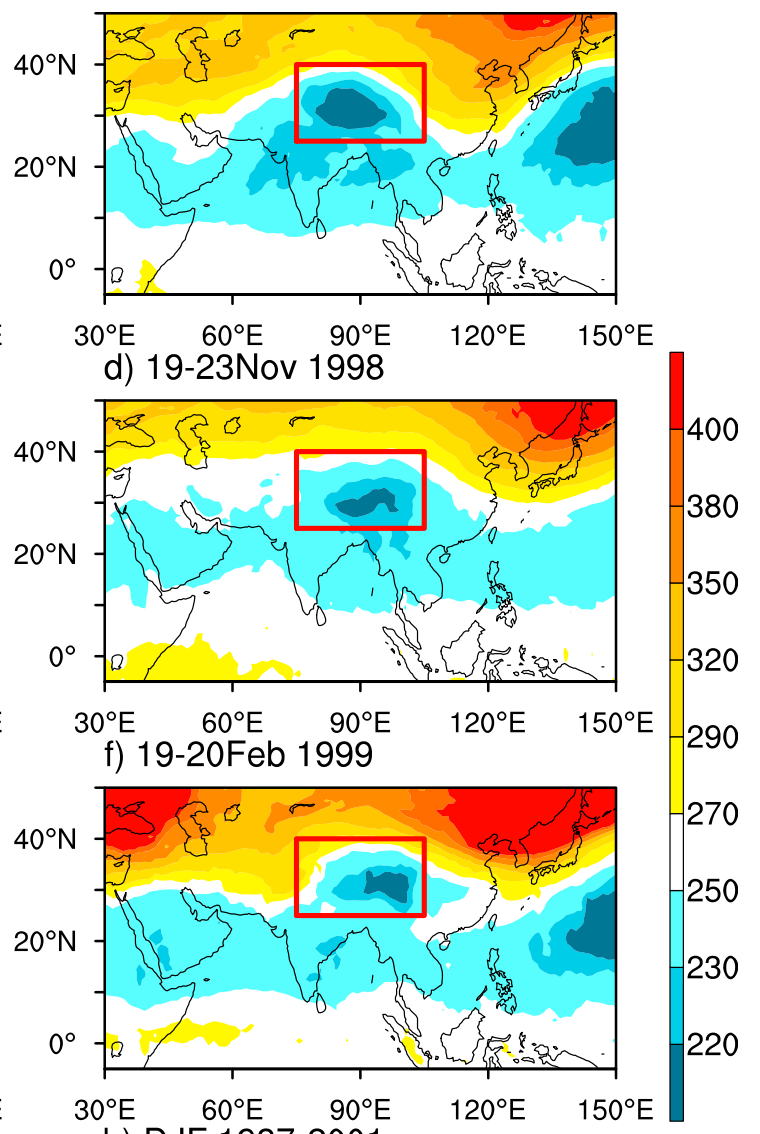

h) DJF 1987-2001

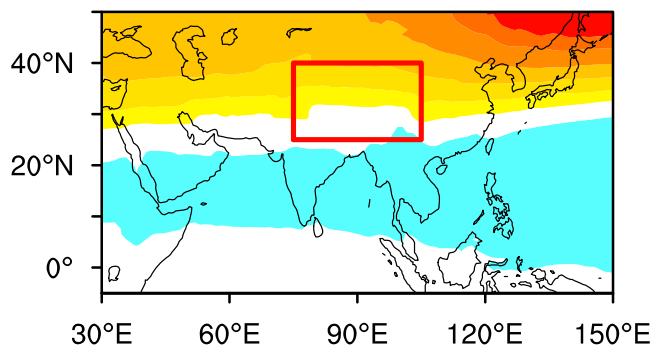

Figure 1. Distribution of wintertime TCO (DU) from TOMS observations: (a) 29 November-1 December 1987 average; (b) 9-12 December 1987 average; (c) 8-10 February 1993 average; (d) 19-23 November 1998 average; (e) 23-25 January 1999 average; (f) 19-20 February 1999; (g) 18-20 December 2001 average; (h) wintertime (December-January February) average between 1987-2001. The red boxes indicate the region of the ozone minimum.

events in November 1998 can also be considered as a whole (the November 1998 event).

\section{TCO Reductions and Ozone Profiles From Observations}

[12] Figure 1 shows the geographical distribution of TCO from TOMS observations during seven persistent ozone minimum events over the TP region (Figures 1a-1g). The multi-year wintertime mean (i.e., average for DecemberFebruary between 1987 and 2001) TCO distribution is also shown, in Figure 1h. In contrast to the multi-year mean state, there is a prominent TCO minimum over the TP region in Figures $1 \mathrm{a}-1 \mathrm{~g}$, each marked with a box. In addition, in four out of the seven cases (see Figures 1a-1c and 1f-1g), a secondary ozone minimum center is located over the subtropical northwestern Pacific and is closely associated with the midstratospheric Aleutian High [Han et al., 2005]. In this study, we only focus on the ozone minimum centers over the TP region.

[13] To illustrate the vertical structure of these ozone minimum events, we selected GOME ozone profiles taken over the TP region during the events after 1995 (i.e., events in 1998, 1999, and 2001) and compared them with the reference profiles, i.e., the 10 day average profile before the first date of each event (see Table 2). Figure 2 shows the contribution of ozone decrease $(15-50 \mathrm{~km})$ in each event relative to the reference profile. In each of these case studies, more than 

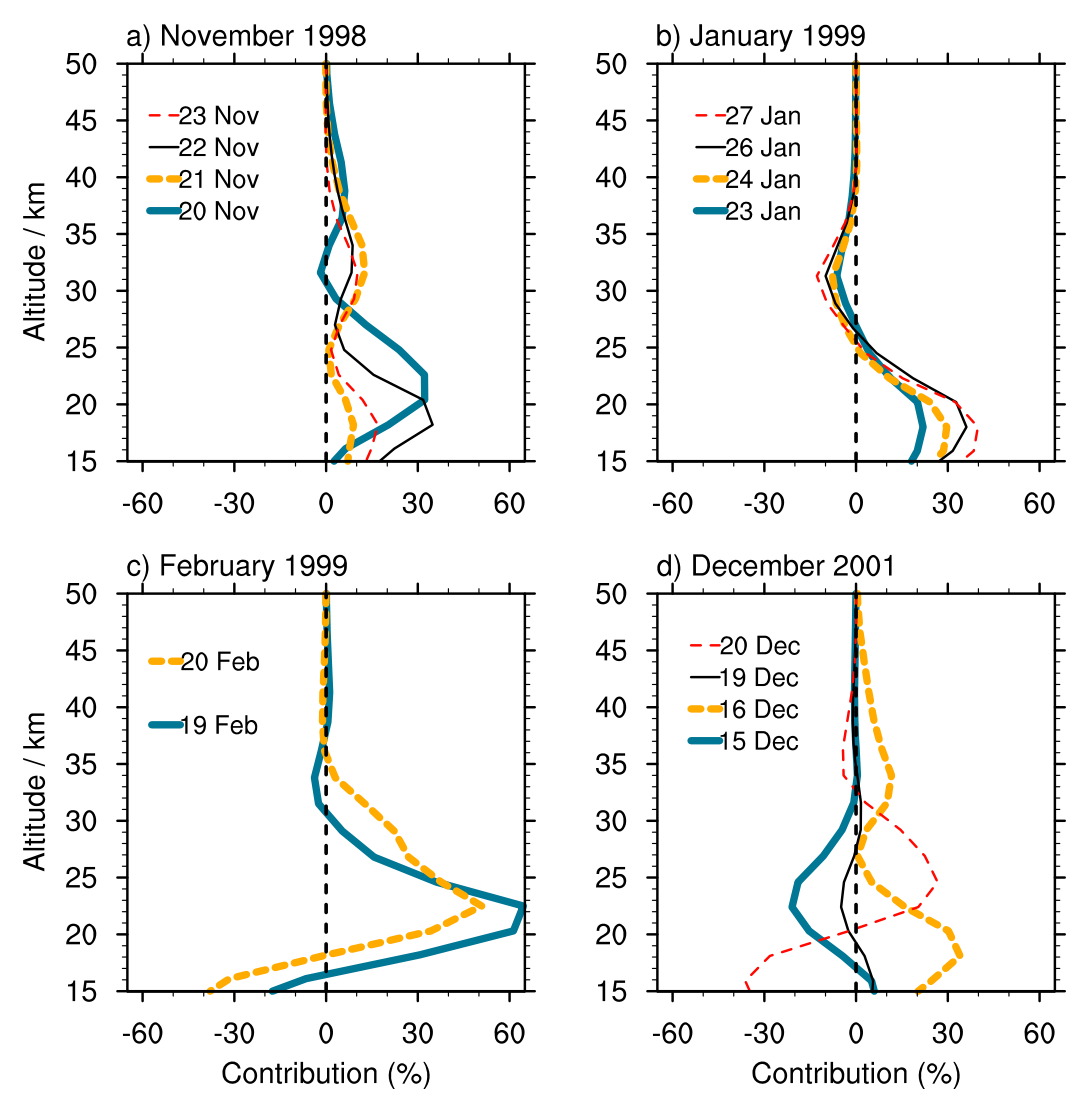

Figure 2. Contributions to the ozone decrease between 15 and $50 \mathrm{~km}$ in each ozone minihole (OMH) case derived from Global Ozone Monitoring Experiment (GOME) ozone profiles within the Tibetan Plateau (TP) region: (a) November 1998 event; (b) January 1999 event; (c) February 1999 event; (d) December 2001 event. Ozone variation on each day was derived by subtracting the 10 day average before the occurrence date of each event.

70 GOME profiles, which adequately sample the TP region, are selected in our calculation (see Table 2). GOME ozone profiles show different variation in the vertical distribution during each event. For example, in the November 1998, February 1999, and December 2001 events, the ozone reduction exists in two vertical layers, i.e., the UTLS region (25-15 km or below) and the MS region (25-40 km). However, in the January 1999 event, pronounced ozone reduction only takes place in the UTLS region, with a slight increase in MS column ozone. That is to say, the TCO reduction in the January 1999 event can be mostly attributed to processes below $25 \mathrm{~km}$. Moreover, Figures $2 \mathrm{a}$ and $2 \mathrm{~d}$ also indicate the temporal evolution of dynamics contributing to ozone reduction in different vertical layers. For example, in the November 1998 event, the UTLS ozone reduction peaks on
21 and 22 November and rapidly recovers after 23 November, resulting from the anomalies of tropopause and subtropical jet (as shown in section 4.1 and Figure 4d). The MS ozone reduction begins on 20 November and increases gradually in the following three days as a result of the development of the polar vortex (as shown in section 4.2 and Figure 7). A similar evolution in the 2001 event can be derived from Figure $2 \mathrm{~d}$. The rapid decrease and recovery of ozone above $30 \mathrm{~km}$ are closely related with the rapid movement of the LOPs inside the strongly developed stratospheric Aleutian High (as shown in section 4.2 and Figure 5d). After the recovery of the ozone above $30 \mathrm{~km}$, the ozone concentrations between 20 and $30 \mathrm{~km}$ decrease prominently on 20 December 2001. Time evolution of vertical ozone reduction (see Figure 2d) suggests that there might be different dynamics responsible for ozone variation

Table 2. Reduction in the Total Column Ozone From Total Ozone Mapping Spectrometer Observations and Variation in the Middle Stratosphere $(25-40 \mathrm{~km})$ Column Ozone From Global Ozone Monitoring Experiment Observations Over the Tibetan Plateau Region $\left(25^{\circ}-40^{\circ} \mathrm{N}, 75^{\circ}-105^{\circ} \mathrm{E}\right)$ as Marked With Boxes in Figure 1 During Four Extreme Ozone Minimum Events ${ }^{\mathrm{a}}$

\begin{tabular}{ccccc}
\hline Events & TCO Variation (DU) & Ref. Dates (Number of Samples) & Variation in MS (Number of Samples) & MS Contribution \\
\hline Nov 1998 & -13.5 & 5-15 Nov (186) & $-5.4(77)$ & $40 \%$ \\
Jan 1999 & -20.2 & 13-22 Jan (187) & $+5.5(86)$ & 0 \\
Feb 1999 & -10.4 & 9-18 Feb (182) & $-3.8(55)$ & $36.5 \%$ \\
Dec 2001 & -9.7 & 5-14 Dec (136) & $-1.5(76)$ & $15.5 \%$ \\
\hline
\end{tabular}

\footnotetext{
${ }^{a}$ The variations in total column ozone (TCO) and middle stratosphere (MS) column ozone are derived by comparison with the reference dates. The number
} of samples for each event and for reference dates and event are also listed. 

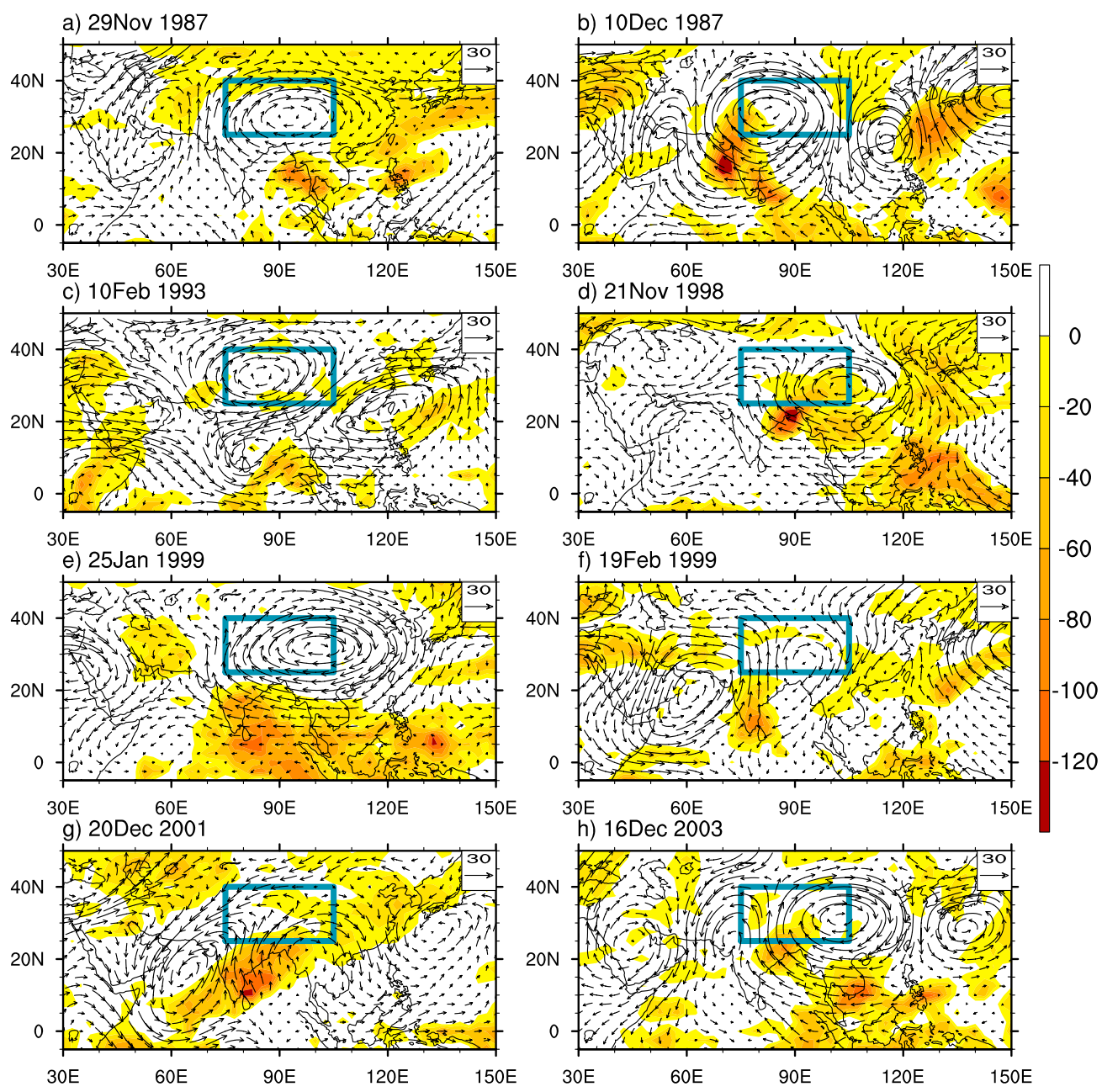

Figure 3. Anomalous wind components (vectors: $\mathrm{m} / \mathrm{s}$ ) at the $200 \mathrm{hPa}$ pressure surface and negative outgoing longwave radiation (OLR) anomaly (shaded: $\mathrm{W} / \mathrm{m}^{2}$ ) from National Centers for Environmental Prediction-National Center for Atmospheric Research (NCEP-NCAR) reanalysis: (a) 29 November 1987; (b) 10 December 1987; (c) 10 February 1993; (d) 21 November 1998; (e) 25 January 1999; (f) 19 February 1999; (g) 20 December 2001; (h) 16 December 2003. As in Figure 1, regions of the ozone minimum are marked with boxes.

below $30 \mathrm{~km}$. As is shown in Figure 6, the pronounced ozone decrease below $30 \mathrm{~km}$ is associated with the eastward advection of ozone-poor air which is stripped off the edge of the displaced polar vortex.

[14] Table 2 presents quantitative results of the MS ozone reduction and its contribution to the TCO reduction. In the four persistent ozone minimum events (November 1998, January 1999, February 1999, and December 2001), the average TCO reduction within the TP region is $13.5,20.2$, 10.4, and 9.7 DU, respectively. As mentioned above, the TCO reduction during the 1999 event is totally caused by UTLS processes (see Figure 2b), while the stratospheric processes in the other three events (November 1998, February 1999, and December 2001) contribute as much as $40 \%$ (5.4 DU), 36.5\% (3.8 DU), and $15.5 \%$ (1.5 DU) of the TCO reduction according to the GOME observations. The standard deviations $(25-50 \mathrm{~km})$ of the selected GOME ozone profiles are within $10 \%$. However, to what extent our results depend on the locations and vertical resolutions of the retrieved ozone profiles is not so easy to be quantified. In the following sec- tion, dynamic processes in both the UTLS and MS regions contributing to the TCO reduction are analyzed using meteorological reanalysis data.

\section{Dynamical Processes}

\subsection{UTLS Dynamics}

[15] C. Liu et al. [2009] showed that more than half of the TCO reduction over the TP region in December 2003 is related to the northward transport of tropical air and the uplift of the tropopause caused by the anomalous anticyclone in the upper troposphere. Figure 3 shows the OLR anomaly (based on the NCEP-NCAR 30 year climatology between 1979 and 2008) and the anomalous horizontal winds at $200 \mathrm{hPa}$ during seven persistent ozone minimum events (Figures $3 \mathrm{a}-3 \mathrm{~g}$ ) and the December 2003 event (Figure 3h). A box marks the location of the TP region $\left(25^{\circ}-40^{\circ} \mathrm{N}, 75^{\circ}-105^{\circ} \mathrm{E}\right)$ in each panel. Similar to the event in December 2003, each lowozone event during winters of 1987-2001 accompanies an anomalous upper-tropospheric anticyclone, although weak in 
several events (Figures $3 \mathrm{f}$ and $3 \mathrm{~g}$ ), around the marked region. As revealed by C. Liu et al. [2009], the poleward flows along the western flank of the anomalous anticyclone also transport ozone-poor air from the tropics to the TP (compare Figures $1 \mathrm{c}, 1 \mathrm{~d}$, and $1 \mathrm{~g}$ with Figures $3 \mathrm{c}, 3 \mathrm{~d}$, and $3 \mathrm{~g}$ ).

[16] The large-scale atmospheric response to off-equatorial convective heating has already been well documented in previous theoretical [e.g., Gill, 1980] and observational [e.g., Rui and Wang, 1990] studies. These well-established dynamic connections also apply in our studies on transport of trace gases in the UTLS region. Figure 3 shows the negative OLR anomalies (enhanced convections) accompanying the anomalous circulation patterns during most of the events. As in the 2003 event, the upper-tropospheric anticyclone anomalies in December 1987, November 1998, and January 1999 are closely related to enhanced convection over the vast central Indo-Pacific, including the eastern Indian Ocean and the western Pacific (see Figures 3a, 3b, 3d, and 3e). However, issues concerning the dynamical formation of the above anticyclonic anomalies should be studied in detail.

[17] The circulation anomalies for each event as shown in Figure 3 cannot perfectly explain the strength of each ozone minimum in Table 1. For example, the anomalous anticyclones on 19 February 1999 (see Figure 3f) and on 20 December 2001 (see Figure 3g) are not as strong as those of the other selected dates, making it more difficult to explain the magnitude of the TCO reduction in these cases (see Table 1 and Figure 1). Moreover, the observed reduction in the MS column ozone (see Figures 2a, 2c, and 2d) must be associated with additional dynamic processes in the stratosphere. The stratospheric origins responsible for the TCO reduction are further analyzed in section 4.2.

[18] Figure 4 displays the NCEP-NCAR meridional circulation, westerly wind, and dynamical tropopause derived from ERA-40 PV isoline (3.5 PVU) along the longitude of each TCO minimum center (see Table 1). In each panel, the black shaded areas indicate topography. Figure $4 \mathrm{~h}$ shows the wintertime average (November-February) meridional circulation, westerly wind from NCEP-NCAR climatology (1979-2008), and dynamical tropopause from ERA-40 climatology (1979-2001) along $95^{\circ} \mathrm{E}$ longitude. The climatological westerly jet and tropopause break are located southward of $30^{\circ} \mathrm{N}$, while the climatological tropopause at $30^{\circ} \mathrm{N}$ is around $200 \mathrm{hPa}(\sim 12 \mathrm{~km})$ (see Figure $\left.4 \mathrm{~h}\right)$. In each of the ozone minimum events, the subtropical westerly jet, which blocks the northward transport, is northward of $30^{\circ} \mathrm{N}$ and is $5-10 \mathrm{~m} / \mathrm{s}$ stronger than the climatological value (Figures 4a-4g). In the December 1987 and February 1993 events, the tropopause breaks and the upper-tropospheric westerly jet cores are located at around $40^{\circ} \mathrm{N}$, i.e., $10^{\circ}$ poleward of the climatological latitude (see Figures $4 \mathrm{~b}$ and $4 \mathrm{c}$ ). During the ozone minimum events the tropopause near $30^{\circ} \mathrm{N}$ moves to $100 \mathrm{hPa}(\sim 16 \mathrm{~km})$ (see Figures $4 \mathrm{a}, 4 \mathrm{~b}, 4 \mathrm{e}$, and $4 \mathrm{f}$ ) or even as high as $70 \mathrm{hPa}(\sim 18 \mathrm{~km})$ (see Figures $4 \mathrm{c}$ and $4 \mathrm{~g})$. In January and February 1999 events, there exist double tropopauses between $35^{\circ}$ and $40^{\circ} \mathrm{N}$ (see Figures $4 \mathrm{e}$ and $4 \mathrm{f}$ ). In each of the event, the uplift of tropopause and the ozone reduction are also coupled with the pronounced meridional transport between 100 and $400 \mathrm{hPa}$ surfaces (see Figures 4a-4g). Therefore, as shown in a previous study [C. Liu et al., 2009], the uplift of the local tropopause and the meridional transport, together with the poleward shift of the westerly jet, are responsible for the pronounced TCO reduction in Tibetan latitudes.

\subsection{Stratospheric Dynamics}

[19] Recent observational studies show that the LOPs inside the stratospheric Aleutian High usually contribute as much as $\sim 10 \%$ of the local TCO reduction [Harvey et al., 2008], and their displacement can explain $\sim 29 \%-46 \%$ of the TCO reduction in the December 2003 ozone minimum event over the TP region [C. Liu et al., 2009]. Moreover, substantial ozone minimum events in Europe and North America are closely related to the displacement of the stratospheric polar vortex [e.g., James et al., 2000; Keil et al., 2007]. Therefore, in this section, we consider the stratospheric processes associating with the LOPs and the polar vortex during the TCO minimum events listed in Table 1.

[20] Figures 5a and 5b show 10 day average geopotential height and horizontal wind vectors at $3 \mathrm{hPa}(\sim 38-39 \mathrm{~km})$ during the December 2001 event. The TP regions are marked with black boxes. The modified PV isolines (35 PVU) are marked with bold solid lines indicating the edge of the polar vortex. The Aleutian High prominently deviates from its climatological position (over the date line) and is located over the TP region. As a result, the polar vortex is prominently transformed and shifted toward the North Atlantic and North America. The Aleutian High develops rapidly after 15 December 2001 (not shown) and causes further displacement of the polar vortex (compare Figures $5 \mathrm{a}$ and $5 \mathrm{~b}$ ). Figures $5 \mathrm{c}$ and 5d show the GOME ozone mixing ratio and horizontal wind vectors at the $3 \mathrm{hPa}$ surface. Decrease in TP ozone concentration above $30 \mathrm{~km}$ (as shown in Figure 2d) can be attributed to development of Aleutian High. For example, in early December, ozone-rich tropical air is transported northeastward toward high latitudes along the western flank of the Aleutian High. As a result, the ozone concentration inside the Aleutian High is $\sim 1$ ppmv lower (see Figure 5c). In middle December, the ozone concentration inside the well-shaped Aleutian High decreases further (compare Figures $5 \mathrm{c}$ and $5 \mathrm{~d}$ ), as expected in previous observational studies [e.g., Harvey et al., 2008]. This suggests the formation of a LOP, which is responsible for the high-level ozone reduction on 16 December 2001 as revealed in the ozone profiles (see Figure 2d). The different feature of vertical ozone reduction in Figure $2 \mathrm{~d}$ suggests that there might be different stratospheric dynamics responsible for the ozone decrease below $30 \mathrm{~km}$. Figure 6 is same as Figure 5, but for $20 \mathrm{hPa}(\sim 25-26 \mathrm{~km})$. Different from the pattern in upper stratosphere $(3 \mathrm{hPa})$, the Aleutian High is far away from the TP region. With the poleward development of the Aleutian High, the polar vortex is displaced toward North Europe (see Figures $6 \mathrm{a}$ and $6 \mathrm{~b}$ ). As shown in the distribution of GOME ozone, there is pronounced northward transport of ozonerich tropical air into the TP region in early December (see Figure 6c). In middle December, instead of the northward transport, the strong westerlies advect ozone-poor air into the TP region (see Figure 6d). As indicated from the meteorological analysis in Figure 6b, these low-ozone air masses can be regarded as being stripped off from the edge of the displaced polar vortex. Therefore, the reduction in stratospheric ozone in the December 2001 event (see Table 2) is derived from the collaboration of the LOP in upper stratosphere (30$40 \mathrm{~km}$ ) and the low-ozone air from the polar vortex edge in 
a) 29 Nov 1987
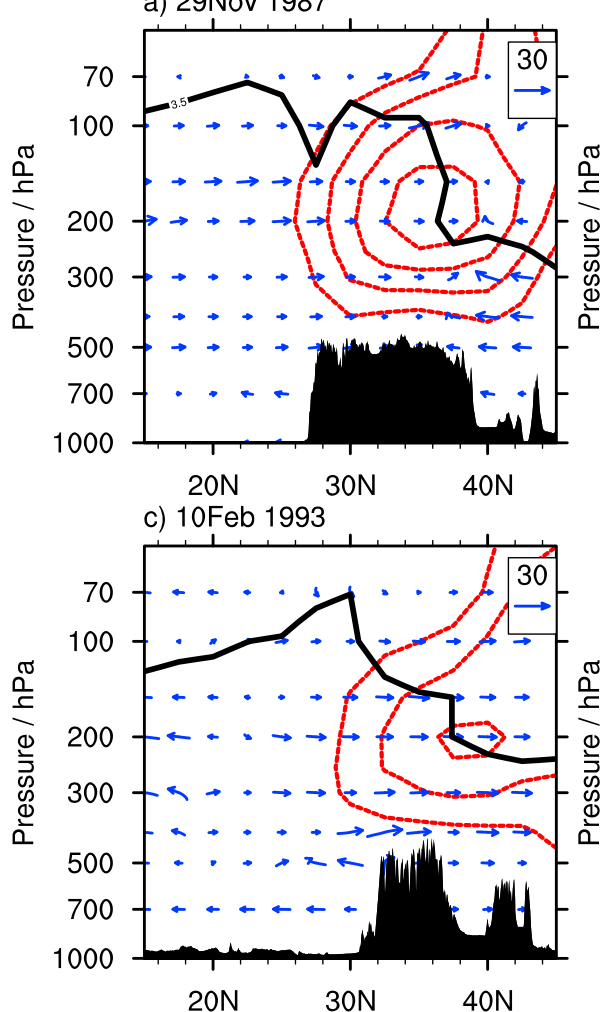

e) 25Jan 1999

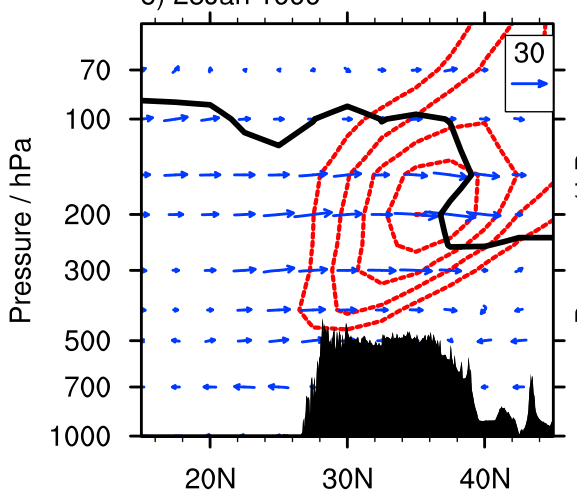

g) $20 \mathrm{Dec} 2001$

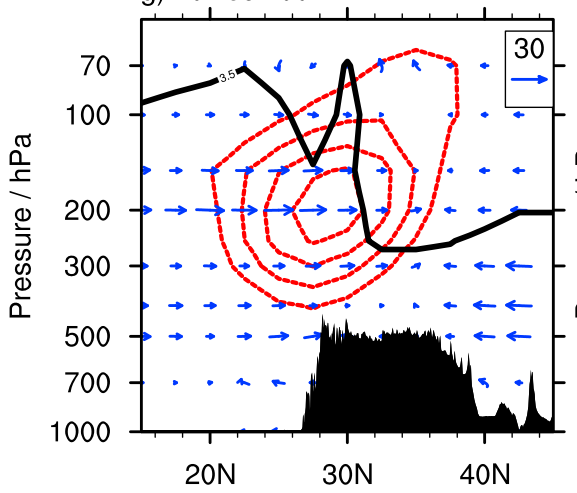

b) $10 \mathrm{Dec} 1987$

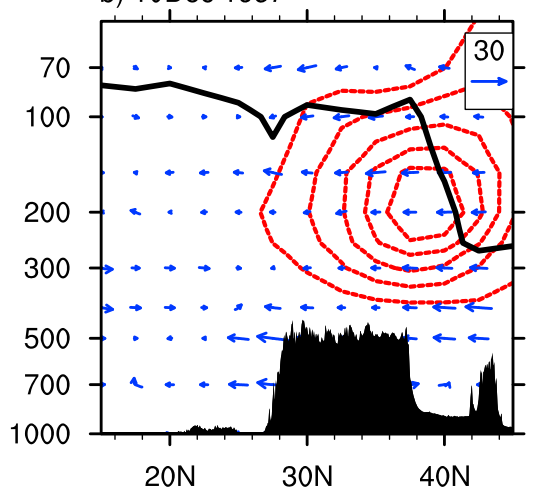

d) 21 Nov 1998

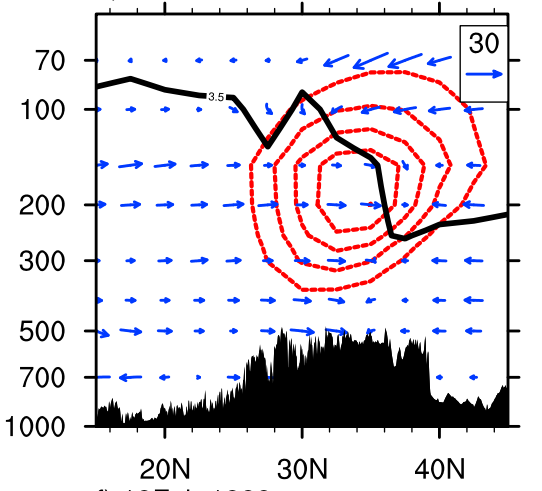

f) $19 \mathrm{Feb} 1999$

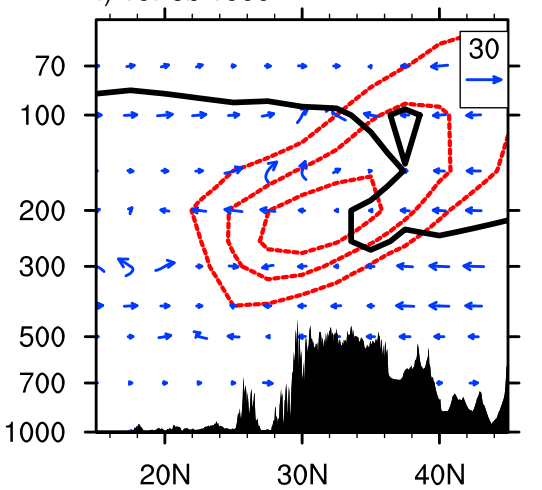

h) NDJF climatology along $95^{\circ} \mathrm{E}$

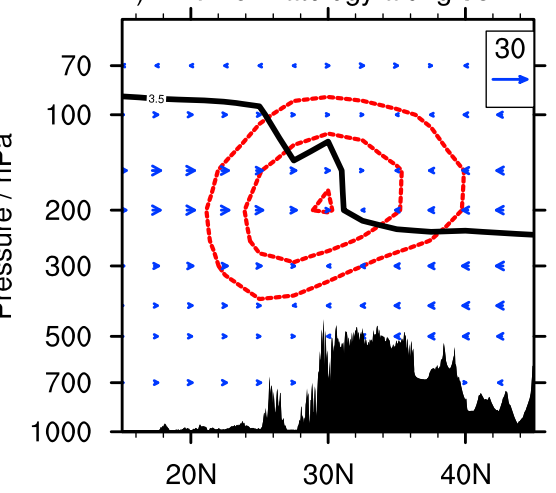

Figure 4. Meridional circulation (vectors, meridional velocity: $\mathrm{m} / \mathrm{s}$; vertical velocity: $\mathrm{m} / \mathrm{s} \times 10$ ) and eastward wind (dotted contour, above $30 \mathrm{~m} / \mathrm{s}$ is shown, interval $10 \mathrm{~m} / \mathrm{s}$ ) at the longitude of each ozone minimum center as shown in Figure 1: (a) 29 November 1987; (b) 10 December 1987; (c) 10 February 1993; (d) 21 November 1998; (e) 25 January 1999; (f) 19 February 1999; (g) 20 December 2001; (h) wintertime (November-February) average between 1987 and 2001 along $95^{\circ} \mathrm{E}$ longitude. ERA-40 potential vorticity (PV) isolines (3.5 PV units (PVU)) are overlaid for each case to present the location of dynamical tropopause (solid lines). The black shaded areas indicate topography. 

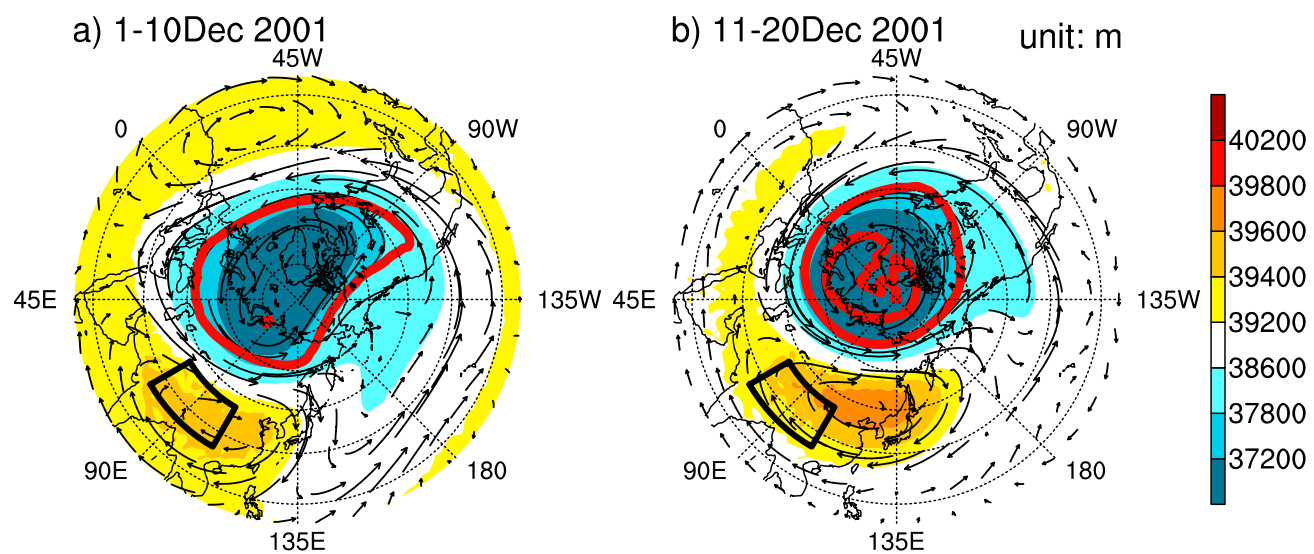

c) 1-10Dec 2001

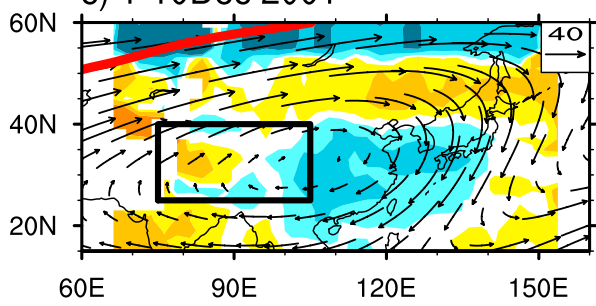

d) $11-20 \mathrm{Dec} 2001$

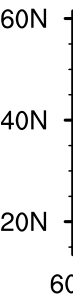

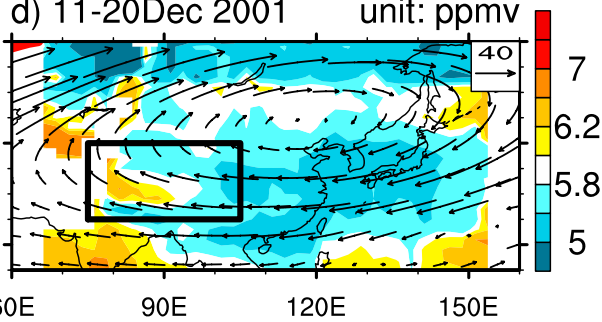

Figure 5. The (top) $3 \mathrm{hPa}$ ERA-40 geopotential height and horizontal wind vectors and (bottom) Global Ozone Monitoring Experiment (GOME) ozone volume mixing ratio for (left) 1-10 December 2001 and (right) 11-20 December 2001. The bold white PV isoline represents the edge of polar vortex. The TP region is marked with a black box.
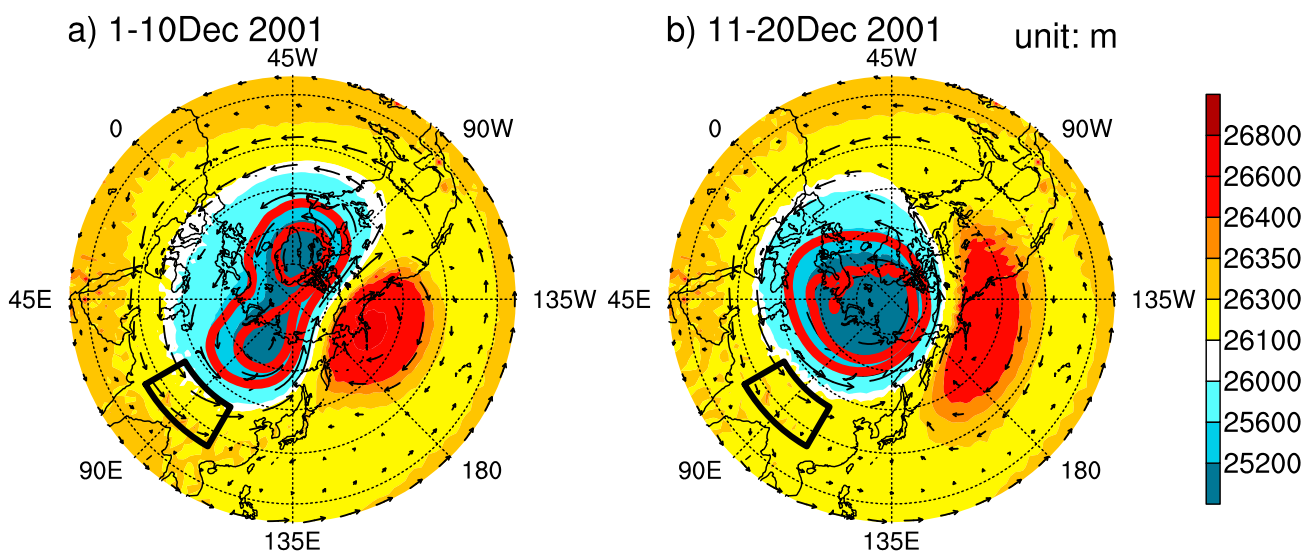

\section{C) $1-10 \mathrm{Dec} 2001$}

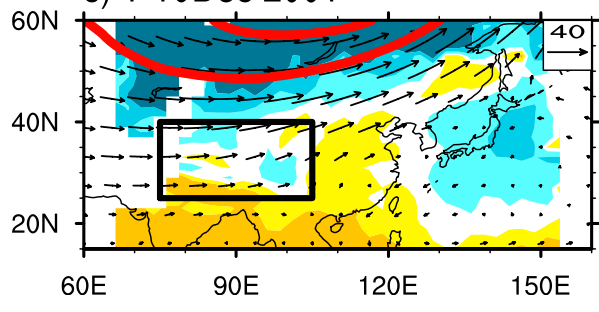

d) 11-20Dec 2001 unit: ppmv

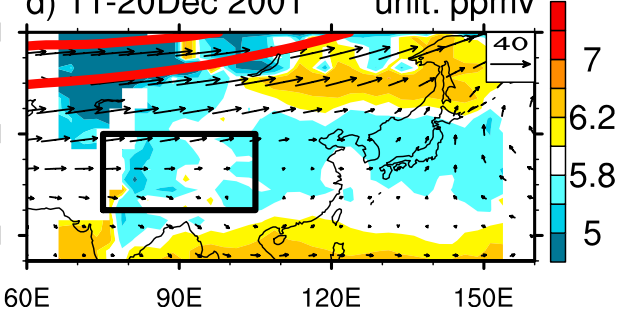

Figure 6. The (top) $20 \mathrm{hPa}$ ERA-40 geopotential height and horizontal wind vectors and (bottom) GOME ozone volume mixing ratio for (left) 1-10 December 2001 and (right) 11-20 December 2001. The bold white PV isoline represents the edge of polar vortex. The TP region is marked with a black box. 

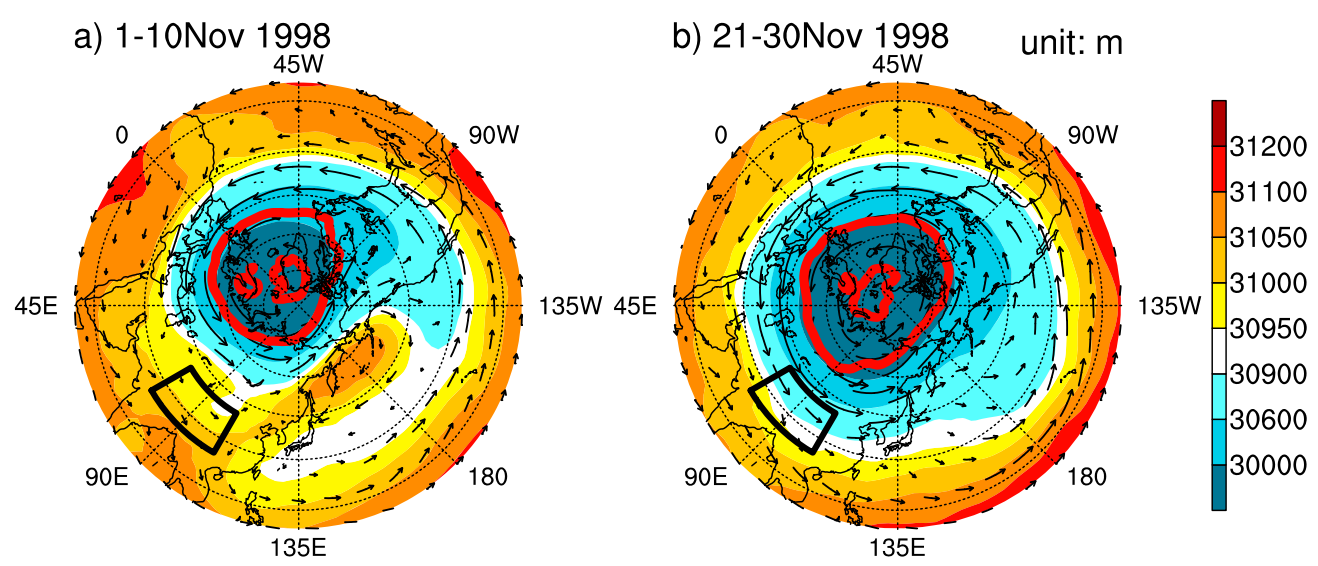

c) 1-10Nov 1998

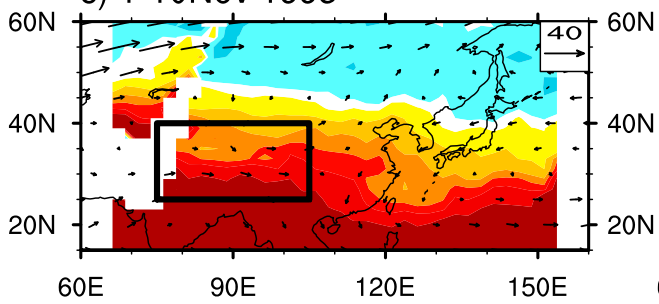

d) 21-30Nov 1998

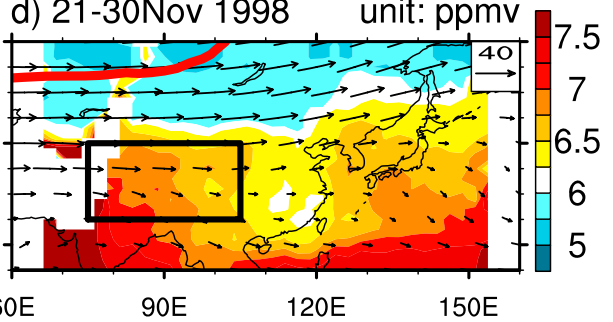

Figure 7. The (top) $10 \mathrm{hPa}$ ERA-40 geopotential height and horizontal wind vectors and (bottom) GOME ozone volume mixing ratio for (left) 1-10 November 1998 and (right) 21-30 November 1998. The bold white PV isoline represents the edge of polar vortex. The TP region is marked with a black box.

middle stratosphere $(20-30 \mathrm{~km})$. However, the contribution of LOP to the TCO reduction is much weaker in this event.

[21] Figure 7 is as Figure 5 but for the $10 \mathrm{hPa}$ pressure surface in the November 1998 event. In contrast to a LOP, ozone is reduced over the TP (refer to Figure 2a) due to the equatorward expansion of the stratospheric polar vortex. For example, during early November 1998, the polar vortex at the $10 \mathrm{hPa}$ surface is compact and generally located within the polar region (see Figure 7a). Meanwhile, the geopotential height over the TP region is relatively high, with high ozone concentration extending from the tropical region (see Figure 7c). However, with the deepening and expansion of the polar vortex during late November (see the modified PV isoline in Figure 7d), the geopotential height over the TP and East Asia decreases with southward advection of ozone-poor air masses from higher latitudes (see Figures $7 \mathrm{~b}$ and $7 \mathrm{~d}$ ). As a result, the stratospheric ozone over the TP region decreases gradually (see Figure 2a), contributing up to $40 \%$ of the TCO reduction (see Table 2).

[22] Figure 8 is as Figure 5 but for the $20 \mathrm{hPa}$ surface in February 1999. In early February, the stratospheric Aleutian High is weak near the date line and the stratospheric polar vortex is compact (see Figure 8a). As a result, the stratospheric ozone concentration over the TP region is undisturbed by the polar vortex and is relatively high (see Figure 8c). However, in middle February, the polar vortex is prominently shifted toward East Asia by the rapidly developing Aleutian High before the SSW event in late February 1999 [Charlton et al., 2004]. With the equatorial displacement of the polar vortex (see Figure 8d), the Tibetan ozone concentration at $20 \mathrm{hPa}$ decreases as much as $1 \mathrm{ppmv}$ (compare Figures $8 \mathrm{c}$ and $8 \mathrm{~d}$ ). As a result, the MS ozone decrease over the TP region (also see Figure 2c) contributes $36.5 \%$ of the pronounced TCO decrease in the February 1999 event (see Table 2).

[23] Figure 9 shows the horizontal winds and geopotential height at $20 \mathrm{hPa}$ surface in the January 1993 event. Since this event only lasts for one day, we compare it with the 10 day average between 10 and 20 January 1993. Similar to the February 1999 event, the stratospheric polar vortex is greatly transformed by the developing Aleutian High in early January 1993. As a result, the stratospheric polar vortex elongates and extends two troughs toward East Asia and North Atlantic. The southward advection of polar air associating with the East Asian trough can reduce the stratospheric ozone concentration over the TP. However, as no ozone observation is available, it is impossible to quantify its contribution to the TCO reduction in the present study.

[24] Figure 10 is as Figure 9 but for $10 \mathrm{hPa}$ pressure surface in the November-December 1987 event. Evolution of the geopotential height in the MS (Figures 10a-10d) shows the development of a major SSW event [e.g., Baldwin and Dunkerton, 1989], during which the Aleutian High moved over the pole (Figures 10b and 10c) and decayed in late December (Figure 10d). Although there are no satellite observations of the stratospheric ozone, a pronounced decrease in the stratospheric ozone can be deduced from the close relationship between the vortex remnants and low-ozone concentrations. Owing to the rapid movement of the vortex and anticyclone during this time, the four TCO minimum events may be regarded as a single event.

[25] For events before 1995 (the beginning of the GOME observations), we can only diagnose the stratospheric dynamics qualitatively using ERA-40 data. In the February 1993 event and the other two transient events (17 December 

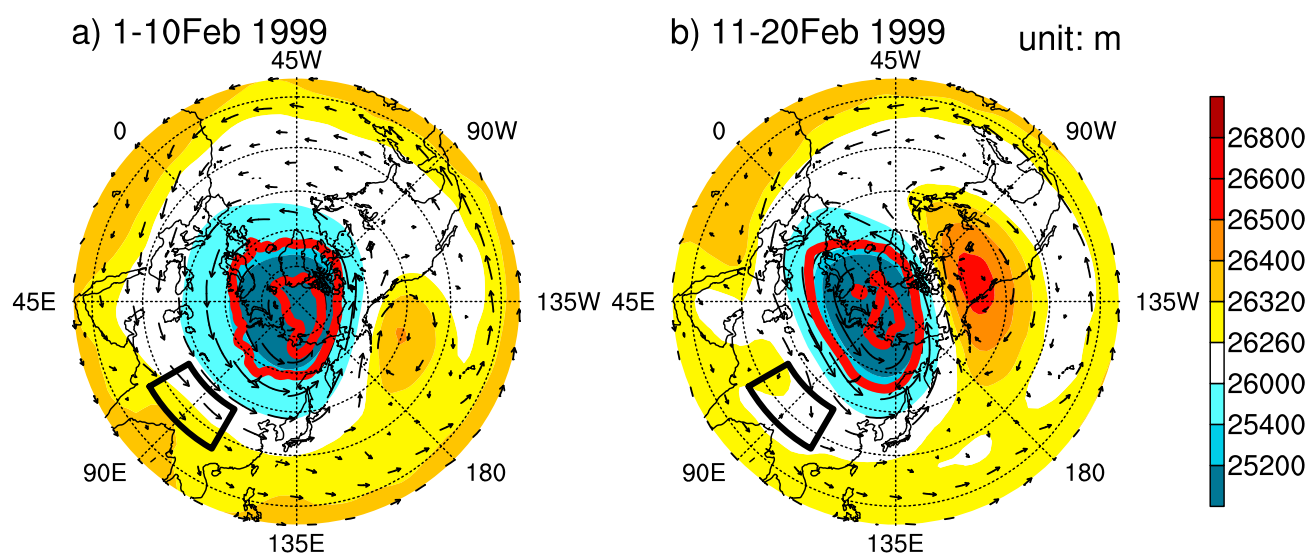

\section{c) 1 -10Feb 1999}

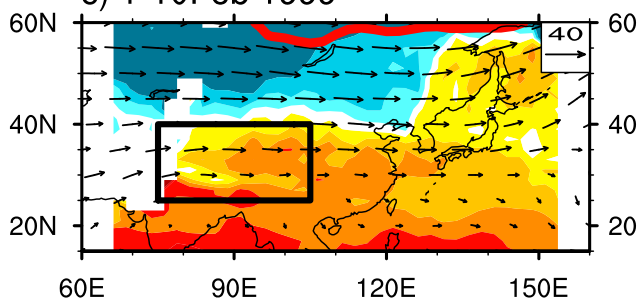

d) 11-20Feb 1999

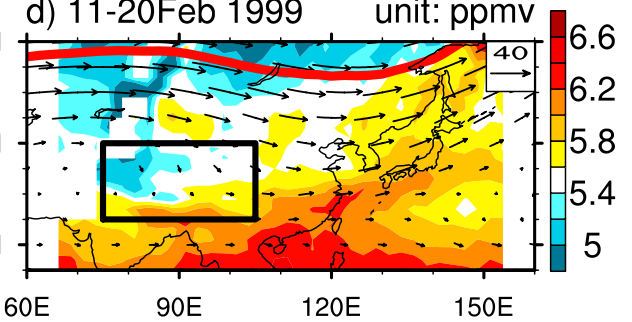

Figure 8. The (top) $20 \mathrm{hPa}$ ERA-40 geopotential height and horizontal wind vectors and (bottom) GOME ozone volume mixing ratio for (left) 1-10 February 1999 and (right) 11-20 February 1999. The bold white $\mathrm{PV}$ isoline represents the edge of polar vortex. The TP region is marked with a black box.

1996 and 30 October 2000), no prominent displacement of the polar vortex or the Aleutian High can be deduced from the analysis data (not shown). Therefore, considering the stratospheric processes, the 13 extreme ozone minimum events in Table 1 can be combined into nine independent events (see Table 3). Table 3 also summarizes these events' relations with stratospheric planetary-scale systems (the stratospheric polar vortex and the LOP inside the stratospheric Aleutian High) and stratospheric sudden warming events.

\section{Summary and Discussion}

[26] This work is an extension of our recent case study on the record TP ozone minimum event during December 2003
[C. Liu et al., 2009]. In the present study, both satellite observations (TOMS and GOME) and meteorological reanalysis (NCEP-NCAR and ERA-40 data) are applied to 13 extreme ozone minimum events during the northern winters of 1987-2001. Results show that all of the above events are closely related to variation in UTLS dynamics (below $25 \mathrm{~km}$ ), i.e., the uplift of the local tropopause and northward transport of tropical ozone-poor air associated with an anomalous anticyclone in the upper troposphere. This mechanism was first proposed in our previous study [C. Liu et al., 2009]. However, the anomalous circulations responsible for the UTLS ozone reduction are not necessarily phase-locked with the tropical MJO activities as in our earlier study. This study

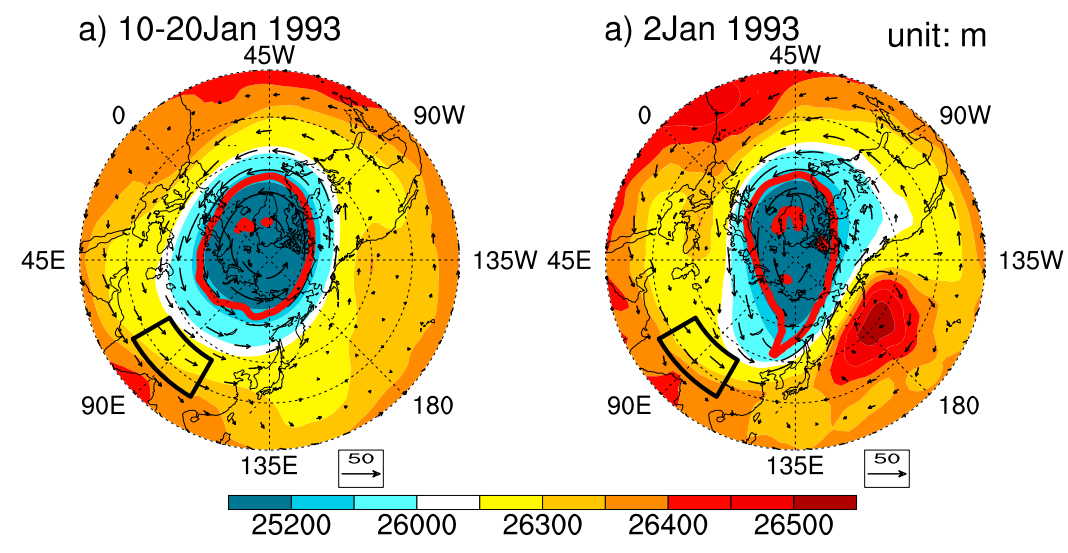

Figure 9. Horizontal wind components (vectors: $\mathrm{m} / \mathrm{s}$ ) and geopotential height (shaded: $\mathrm{m}$ ) at the $20 \mathrm{hPa}$ pressure surface: (a) 10-20 January 1993 average; (b) 2 January 1993. The bold white PV isoline represents the edge of polar vortex. Regions of the ozone minimum are marked with boxes. 


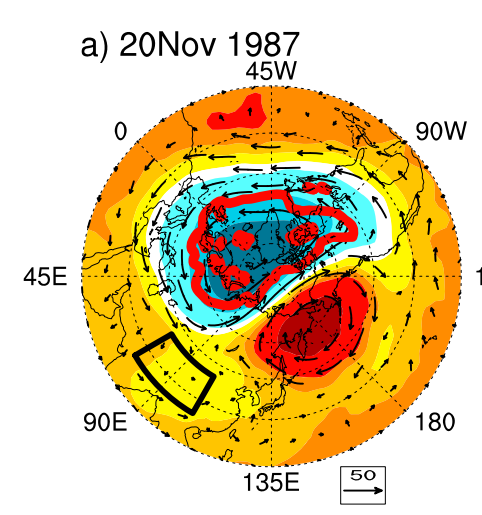

c) $10 \mathrm{Dec} 1987$

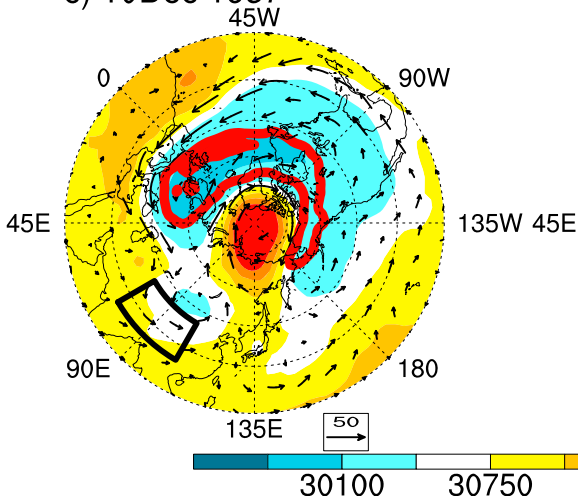

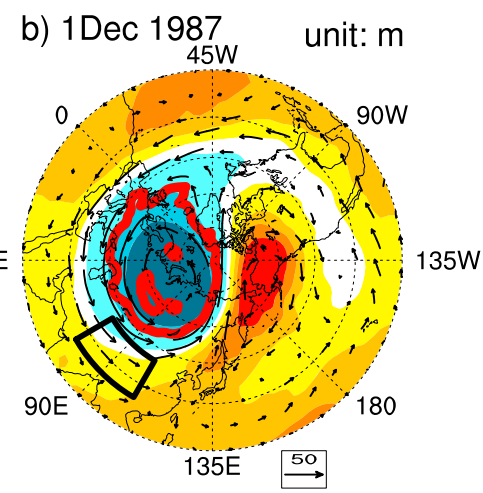

d) $22 \mathrm{Dec} 1987$

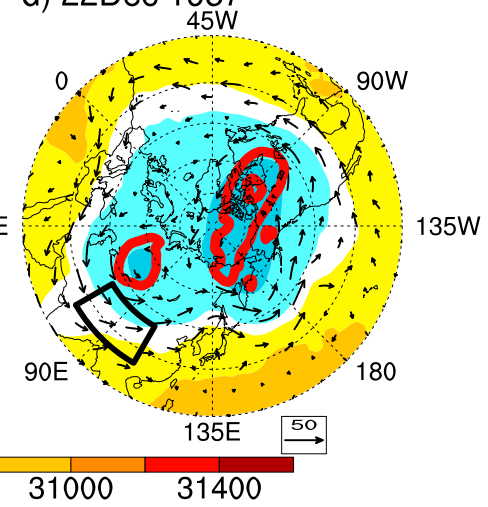

Figure 10. Same as Figure 9 but for the $10 \mathrm{hPa}$ pressure surface on (a) 20 November, (b) 1 December, (c) 10 December, and (d) 22 December 1987.

shows that anticyclonic anomalies during 1987, 1996 (not shown), 1998, 1999, 2000 (not shown), and 2001 winters are coupled with anomalous deep convective heating in the tropics, although more detailed studies should be devoted to their dynamic origins.

[27] By considering stratospheric processes, the 13 events in Table 1 are synthesized into nine independent events (see Table 3). Further study shows that five of the nine events (excepting two persistent events in February 1993 and January 1999 and two transient events on 17 December 1996 and 30 October 2000) are coupled with stratospheric processes. These stratospheric processes likely cause further reduction in stratospheric column ozone. On the basis of retrieved ozone profiles from GOME observations (becoming available as early as 1995) during the November 1998, February 1999, and December 2001 events, stratospheric dynamics between 25 and $40 \mathrm{~km}$ can contribute as much as $15 \%-40 \%$ of the TCO reduction. This magnitude is consistent with the value in our earlier case study $(\sim 29 \%-46 \%)$ and might still depend on the locations and vertical resolution of the observations. Diagnostics from the GOME observations and ERA-40 dynamics shows that the stratospheric column ozone reduction over the TP region can be generally attributed to the dynamics (development and/or displacement) of the polar vortex and Aleutian High (in the NovemberDecember 1987, 2 January 1993, November 1998, February 1999, and December 2001 events). Of all the events between 1987 and 2001, the contribution of LOP to the TCO reduction

Table 3. Independent Ozone Minimum Events Over the Tibetan Plateau Region and Their Associations With Stratospheric Factors (and Stratospheric Sudden Warming Events) ${ }^{\text {a }}$

\begin{tabular}{ccccc}
\hline No. & Duration (days) & Type & Stratospheric Factor & Sudden Warming Event \\
\hline 1 & Nov and Dec 1987 (12) & $\mathrm{P}$ & Polar vortex & Yes \\
2 & Jan 1993 (1) & T & Polar vortex & No \\
3 & Feb 1993 (3) & P & None & No \\
4 & Dec 1996 (1) & T & Polar vortex & No \\
5 & Nov 1998 (6) & P & None & Yoes \\
6 & Jan 1999(3) & P & None & No \\
7 & Feb 1999 (2) & P & Polar vortex and LOP & Yes \\
8 & Oct 2000 (1) & LOP & Yes \\
9 & Dec 2001 (3) & P & P & \\
$*$
\end{tabular}

${ }^{\mathrm{a}}$ The stratospheric processes over the Tibetan Plateau (TP) region are under consideration here, and the polar vortex and the low-ozone pocket (LOP) inside the Aleutian High are taken as the two main stratospheric factors affecting ozone minimum events over the TP region. P and T are as defined in Table 1. The December 2003 event is also listed here (marked with an asterisk). 
can be generally neglected, except in the December 2001 event. In the December 2001 event, the LOP's contribution to upper stratospheric ozone concentration is also noted. It leads to a slight decrease in the TP ozone concentration above $30 \mathrm{~km}$ in middle December 2001 . However, this is relatively small when compared to the effect of polar vortex. Additionally, the interaction between the two planetary-scale systems of polar vortex and Aleutian High is responsible for a substantial fraction of major SSW events [e.g., Scott and Dritschel, 2006]. For example, during early December 1987 and early January 1993, the polar vortex disturbances are coupled with the poleward development of the Aleutian High (see Figures 5 and 8). In addition, the rapid enhancement of the Aleutian High during middle February 1999 (see Figure 8) and middle December 2001 (see Figure 5) can also be regarded as precursors of the late February 1999 and the 2001-2002 stratospheric warming events. The westward intrusion of the LOPs in December 2003 (see Figures 2e-2h in the earlier study [C. Liu et al., 2009]) is also followed by the 2003-2004 SSW event [e.g., Y. Liu et al., 2009a]. Therefore, the stratospheric column ozone reduction from the LOPs differs from that in the North Atlantic/European sector and can be regarded as a unique mechanism for TCO reduction in the North Pacific/East Asian sector. However, more observational study should be devoted to quantifying the effect of LOP on the TCO in East Asia.

[28] Acknowledgments. This work was funded by the National Basic Research Program of China (grant 2010CB428604), National Science Foundation of China (grant 40633015), and the Dragon 2 Programme (ID: 5311). We thank the European Space Agency and the German Aerospace Center for their ongoing cooperation in the GOME program. The meteorological analysis was kindly provided by ECMWF and NCEP. Research at SAO was funded by NASA and the Smithsonian Institution.

\section{References}

Antón, M., M. L. Cancillo, A. Serrano, J. M. Vaquero, and J. A. García (2007), Ozone mini-hole over southwestern Spain during January 2004: Influence over ultraviolet radiation, Geophys. Res. Lett., 34, L10808, doi:10.1029/2007GL029689.

Baldwin, M. P., and T. J. Dunkerton (1989), The stratospheric major warming of early December 1987, J. Atmos. Sci., 46, 2863-2884.

Bian, J. (2009), Features of ozone mini-hole events over the Tibetan Plateau, Adv. Atmos. Sci., 26(2), 305-311.

Bian, J., G. Wang, H. Chen, D. Qi, D. Lü, and X. Zhou (2006), Ozone mini-hole occurring over the Tibetan Plateau in December 2003, Chin. Sci. Bull., 51(7), 885-888.

Cai, Z., Y. Wang, X. Liu, X. Zheng, K. Chance, and Y. Liu (2009), Validation of GOME ozone profiles and tropospheric column ozone with ozonesonde over China (in Chinese), J. Appl. Meteorol. Sci., 20(3), $337-345$.

Chance, K. V., J. P. Burrows, D. Perner, and W. Schneider (1997), Satellite measurements of atmospheric ozone profiles, including tropospheric ozone, from ultraviolet/visible measurements in the nadir geometry: A potential method to retrieve tropospheric ozone, J. Quant. Spectrosc. Radiat. Transfer, 57(4), 467-476.

Charlton, A. J., A. O’Neill, W. A. Lahoz, and A. C. Massacand (2004), Sensitivity of tropospheric forecasts to stratospheric initial conditions, Q. J. R. Meteorol. Soc., 130, 1771-1792.

Farman, J. C., B. G. Gardiner, and J. D. Shanklin (1985), Large losses of total ozone in Antarctica reveal seasonal $\mathrm{ClO}_{x} / \mathrm{NO}_{x}$ interaction, Nature, $315,207-210$.

Gill, A. E. (1980), Some simple solutions for heat-induced tropical circulation, Q. J. R. Meteorol. Soc., 106(449), 447-462.

Han, J., K. Yamazaki, and M. Niwano (2005), The winter ozone minimum over the subtropical northwestern pacific, J. Meteorol. Soc. Jpn., 83(1), 57-67.

Harvey, V. L., and M. H. Hitchman (1996), A climatology of the Aleutian High, J. Atmos. Sci., 53(14), 2088-2101.
Harvey, V. L., M. H. Hitchman, R. B. Pierce, and T. D. Fairlie (1999), Tropical aerosol in the Aleutian High, J. Geophys. Res., 104(D6), 6281-6290, doi:10.1029/1998JD200094.

Harvey, V. L., R. B. Pierce, M. H. Hitchman, C. E. Randall, and T. D. Fairlie (2004), On the distribution of ozone in stratospheric anticyclones, J. Geophys. Res., 109, D24308, doi:10.1029/2004JD004992.

Harvey, V. L., C. E. Randall, G. L. Manney, and C. S. Singleton (2008), Low-ozone pockets observed by EOS-MLS, J. Geophys. Res., 113, D17112, doi:10.1029/2007JD009181.

Hendon, H. H., and M. L. Salby (1994), The life cycle of the MaddenJulian Oscillation, J. Atmos. Sci., 51(15), 2225-2237.

Hoerling, M. P., T. K. Schaack, and A. J. Lenzen (1991), Global objective tropopause analysis, Mon. Weather Rev., 119, 1816-1831.

James, P. M. (1998a), An interhemispheric comparison of ozone mini-hole climatologies, Geophys. Res. Lett., 25(3), 301-304, doi:10.1029/ 97GL03643.

James, P. M. (1998b), A climatology of ozone mini-holes over the Northern Hemisphere, Int. J. Climatol., 18, 1287-1303.

James, P. M., D. Peters, and D. W. Waugh (2000), Very low ozone episodes due to polar vortex displacement, Tellus, Ser. B, 52, 1123-1137.

Kalnay, E., et al. (1996), The NCEP/NCAR 40-year reanalysis project, Bull. Am. Meteorol. Soc., 74, 2331-2342.

Keil, M., D. R. Jackson, and M. C. Hort (2007), The January 2006 low ozone event over the UK, Atmos. Chem. Phys., 7, 961-972.

Kiladis, G. N., K. H. Straub, G. C. Reid, and K. S. Gage (2001), Aspects of interannual and intraseasonal variability of the tropopause and lower stratosphere, Q. J. R. Meteorol. Soc., 127, 1961-1983.

Koch, G., H. Wernli, C. Schwierz, J. Staehelin, and T. Peter (2005), A composite study on the structure and formation of ozone miniholes and minihighs over central Europe, Geophys. Res. Lett., 32, L12810, doi:10.1029/ 2004GL022062.

Lait, L. R. (1994), An alternative form for potential vorticity, J. Atmos. Sci., 51(12), 1754-1759

Liu, C., Y. Liu, Z. Cai, S. Gao, D. Lü, and E. Kyrölä (2009), A MaddenJulian Oscillation-triggered record ozone minimum over the Tibetan Plateau in December 2003 and its association with stratospheric "lowozone pockets," Geophys. Res. Lett., 36, L15830, doi:10.1029/ 2009GL039025.

Liu, X., K. Chance, C. E. Sioris, R. J. D. Spurr, T. P. Kurosu, R. V. Martin, and M. J. Newchurch (2005), Ozone profile and tropospheric ozone retrievals from the Global Ozone Monitoring Experiment: Algorithm description and validation, J. Geophys. Res., 110, D20307, doi:10.1029/2005JD006240.

Liu, X., K. Chance, C. E. Sioris, T. P. Kurosu, and M. J. Newchurch (2006), Intercomparison of GOME, ozonesonde, and SAGE II measurements of ozone: Demonstration of the need to homogenize available ozonesonde data sets, J. Geophys. Res., 111, D14305, doi:10.1029/ 2005JD006718.

Liu, Y., C. Liu, H. Wang, X. Tie, S. Gao, D. E. Kinnison, and G. P. Brasseur (2009a), Atmospheric tracers during the 2003-2004 stratospheric warming event and impact of ozone intrusions in the troposphere, Atmos. Chem. Phys., 9, 2157-2170.

Liu, Y., Y. Wang, X. Liu, Z. Cai, and K. Chance (2009b), Tibetan middle tropospheric ozone minimum in June discovered from GOME observations, Geophys. Res. Lett., 36, L05814, doi:10.1029/2008GL037056.

Madden, R. A., and P. R. Julian (1971), Detection of a 40-50 day oscillation in the zonal wind in the tropical Pacific J. Atmos. Sci., 28(5), 702-708.

Madden, R. A., and P. R. Julian (1994), Observations of the 40-50-day tropical oscillation-A review, Mon. Weather Rev., 122(5), 814-837.

Manney, G. L., et al. (1994), Chemical depletion of ozone in the Arctic lower stratosphere during winter 1992-93, Nature, 370, 429-434.

Manney, G. L., L. Froidevaux, J. W. Waters, R. W. Zurek, J. C. Gille, J. B. Kumer, J. L. Mergenthaler, A. E. Roche, A. O’Neill, and R. Swinbank (1995), Formation of low-ozone pockets in the middle stratospheric anticyclone.

Morris, G. A., S. R. Kawa, A. R. Douglass, M. R. Schoeberl, L. Froidevaux, and J. Waters (1998), Low-ozone pockets explained, J. Geophys. Res., 103(D3), 3599-3610, doi:10.1029/97JD02513.

Newman, P. A., L. R. Lait, and M. R. Schoeberl (1988), The morphology and meteorology of Southern Hemisphere spring total ozone mini-holes, Geophys. Res. Lett., 15(8), 923-926.

Qiu, J. (2008), The third pole, Nature, 454(7203), 393-396, doi:10.1038/ 4543939.

Randel, W. J., and M. Park (2006), Deep convective influence on the Asian summer monsoon anticyclone and associated tracer variability observed with Atmospheric Infrared Sounder (AIRS), J. Geophys. Res., 111, D12314, doi:10.1029/2005JD006490. 
Rui, H., and B. Wang (1990), Development characteristics and dynamic structure of tropical intraseasonal convection anomalies, J. Atmos. Sci., 47(3), 357-379.

Salby, M. L., and P. F. Callaghan (1993), Fluctuations of total ozone and their relationship to stratospheric air motions, J. Geophys. Res., 98(D2), 2715-2727.

Scott, R. K., and D. G. Dritschel (2006), Vortex-vortex interactions in the winter stratosphere, J. Atmos. Sci., 63(2), 726-740.

Tian, B., Y. L. Yung, D. E. Waliser, T. Tyranowski, L. Kuai, E. J. Fetzer, and F. W. Irion (2007), Intraseasonal variations of the tropical total ozone and their connection to the Madden-Julian Oscillation, Geophys. Res. Lett., 34, L08704, doi:10.1029/2007GL029451.

Uppala, S. M., et al. (2005), The ERA-40 re-analysis, Q. J. R. Meteorol. Soc., 131(612), 2961-3012.

Yeh, T. C., and Y. X. Gao (1979), Meteorology of the Qinghai-Xizang Plateau (in Chinese), 278 pp., Chinese Science Press, Beijing.

Zhou, X., C. Luo, and W. Li (1995), Total column ozone over China and center of low total column ozone over the Tibetan Plateau (in Chinese), Chin. Sci. Bull., 40(15), 1396-1398.
Ziemke, J. R., and S. Chandra (2003), A Madden-Julian Oscillation in tropospheric ozone, Geophys. Res. Lett., 30(23), 2182, doi:10.1029/ 2003 GL018523.

Zou, H. (1996), Seasonal variation and trends of TOMS ozone over Tibet, Geophys. Res. Lett., 23(9), 1029-1032, doi:10.1029/96GL00767.

J. Bian, Z. Cai, C. Liu, and Y. Liu, Key Laboratory of Middle Atmosphere and Global Environment Observation, Institute of Atmospheric Physics, Chinese Academy of Sciences, Beijing 100029 , China.

K. Chance, Harvard-Smithsonian Center for Astrophysics, 60 Garden St., Cambridge, MA 02138, USA.

S. Gao, LACS, Institute of Atmospheric Physics, Chinese Academy of Sciences, Beijing 100029, China.

X. Liu, Goddard Earth Sciences and Technology Center, University of Maryland, 5523 Research Park Dr., Ste 320., Baltimore, MD 21228, USA. 